\title{
The effects of soil manganese status on the bioavailability of soil cobalt for pasture uptake in New Zealand soils
}

\author{
ZHENG LI ${ }^{1}$, R.G. McLAREN ${ }^{1}$ and A.K. METHERELL ${ }^{2}$ \\ ${ }^{1}$ Soil and Physical Sciences Group, ${ }^{2}$ AgResearch, PO Box 84, Lincoln University, Canterbury
}

\begin{abstract}
The effects of soil properties on the availability of cobalt $(\mathrm{Co})$ for pasture uptake have been studied using a wide range of New Zealand soils. There is a strong positive correlation between total or EDTA-extractable Co and manganese (Mn) concentration. However glasshouse studies have shown that $\mathrm{Co}$ availability is inversely related to the $\mathrm{Mn}$ concentration. Across a wide range of soil groups, EDTA-extractable Co is a poor predictor of cobalt availability. $\mathrm{CaCl}_{2}$-extractable $\mathrm{Co}$ was found to decrease with soil $\mathrm{pH}$ and was too $\mathrm{pH}$ sensitive to be a good predictor of Co availability. It is concluded that soil Mn plays a crucial role in soil Co status and has significant effects on plant Co uptake because of its involvement in the soil redox system and the scavenging properties of soil Mn oxides. Co deficiency is more likely to occur and Co fertiliser is less effective on soils with high $\mathrm{Mn}$, especially under dry conditions.
\end{abstract}

Keywords: lime, pasture cobalt, soil cobalt, soil manganese, soil moisture, trace elements

\section{Introduction}

Adequate cobalt $(\mathrm{Co})$ in pasture is essential for ruminant health in New Zealand pastoral agriculture (Andrews 1970). Since the late 1930s, when Co deficiency was diagnosed, many studies have been undertaken in New Zealand in attempts to find more convenient methods of assessing the Co status in soils at the soil group and/ or the farm level (Forbes 1976; Kidson 1937; McLaren et al. 1987; Metherell 1989; O'Connor et al. 1995; Sherrell 1990; Sherrell et al. 1990).

The current soil diagnostic method, 0.02M EDTA extraction, used by AgResearch is not particularly sensitive, and there are problems with its interpretation (O'Connor et al. 1995). Topdressing with Co fertiliser has been widely used to control Co deficiency (Andrews 1970; Sherrell et al. 1990). However variation in the efficacy and durability of Co topdressing to overcome Co deficiency can not be fully explained. An increasing incidence of Co deficient situations have been reported recently, even in areas which previously were believed not to have a Co problem (O'Connor et al. 1995).
Soil Mn plays a crucial role in the fate of soil Co because of the affinity of soil Mn oxides for Co (Adams et al. 1969) and its involvement in oxidation and reduction (redox) reactions. In soils, $\mathrm{Mn}$ is found in soluble $\mathrm{Mn}^{2+}$, insoluble $\mathrm{Mn}^{3+}$ and $\mathrm{Mn}^{4+}$ (Mn oxides) oxidation states. The balance between these forms is controlled by the soil $\mathrm{pH}$ and redox status. Redox reactions are affected by soil moisture and biological activity. It has been hypothesised (Metherell 1989) that these factors are likely to affect the Co status of pasture. An ongoing research programme, carried out by Lincoln University and AgResearch and sponsored by Meat New Zealand, focuses on the effects of soil Mn on soil Co availability for pasture uptake. Using various soil chemical extractions, the impact of soil properties on Co availability over a wide range of New Zealand soils has been examined in glass house trials.

\section{Materials and methods}

\section{Co and Mn in New Zealand Soils}

Fifty-one surface and 45 sub-soil samples were collected from permanent grassland sites throughout New Zealand. Cobalt and Mn extracted by EDTA $(0.02 \mathrm{M})$ and $\mathrm{CaCl}_{2}(0.05 \mathrm{M})$ were determined together with total $\mathrm{Co}, \mathrm{Mn}$, iron $(\mathrm{Fe})$ and aluminium $(\mathrm{Al})$, soil organic carbon $(\mathrm{C})$ and soil $\mathrm{pH}$.

\section{Pot trials in the glass house}

Two pot trials were carried out separately in a glass house.

Pot Trial 1 was conducted to assess the effects of soil properties, added Co and soil moisture conditions, on the availability of Co. Topsoils ( 0 $10 \mathrm{~cm}$ ) from grassland sites throughout New Zealand were used for Pot Trial 1. Soils with $(n=15)$ and without $(\mathrm{n}=18)$ Co treatment $(350 \mu \mathrm{g}$ $\mathrm{CoSO}_{4} \cdot 7 \mathrm{H}_{2} \mathrm{O} / \mathrm{kg}$ ) were kept at field capacity or $70 \%$ field capacity moisture levels after sowing with ryegrass seeds. Pasture $\mathrm{Co}$ and soil $0.05 \mathrm{M} \mathrm{CaCl}_{2}$ extractable $\mathrm{Co}$ and $\mathrm{Mn}$, together with soil $\mathrm{pH}$, were determined after the trial.

Pot Trial 2 was designed to assess the effects of soil $\mathrm{pH}$ and soil moisture conditions on the availability of soil Co for pasture uptake. Four topsoils $(0-10 \mathrm{~cm})$ with a wide range in native $\mathrm{Mn}$ and different soil physical and chemical properties 
Table 1 Some chemical properties of the soils used in Pot Trial 2.

\begin{tabular}{lcccccc}
\hline Soil Name & Soil Group & EDTA-Co $(\mu \mathrm{g} / \mathrm{g})$ & EDTA-Mn $(\mu \mathrm{g} / \mathrm{g})$ & $\mathrm{CaCl}_{2}$-Co $(\mu \mathrm{g} / \mathrm{g})$ & $\mathrm{CaCl}_{2}-\mathrm{Mn}_{(\mu \mathrm{g} / \mathrm{g})}$ & $\mathrm{pH}(\mathrm{initial})$ \\
\hline Selwyn & Recent & 0.68 & 26 & 0.105 & 8 & 5.21 \\
Makarewa & Recent Gley & 0.88 & 157 & 0.060 & 22 & 5.23 \\
Kauroa & Allophanic & 3.35 & 1464 & 0.011 & 67 & 5.38 \\
Taupo & Pumice & 0.62 & 99 & 0.055 & 19 & 5.31 \\
\hline
\end{tabular}

Table 2 Linear correlation coefficients $(r)$ between soil properties in topsoils.

\begin{tabular}{lccccccccc}
\hline & EDTA Co & $\mathrm{CaCl}_{2} \mathrm{Co}$ & Total Mn & EDTA Mn & $\mathrm{CaCl}_{2} \mathrm{Mn}$ & Total Fe & Total Al & Carbon & $\mathrm{pH}$ \\
\hline Total Co & \multirow{2}{*}{$0.72^{*}$} & 0.04 & $0.77^{*}$ & $0.60^{*}$ & 0.27 & $0.72^{*}$ & $0.53^{*}$ & 0.00 & 0.25 \\
EDTA Co & & 0.24 & $0.76^{*}$ & $0.78^{*}$ & $0.63^{*}$ & 0.34 & 0.24 & -0.07 & 0.08 \\
CaCl $_{2}$ Co & & & -0.10 & -0.05 & $0.42^{*}$ & -0.06 & -0.24 & -0.13 & $-0.53^{*}$ \\
Total Mn & & & & $0.94^{*}$ & $0.50^{*}$ & $0.53^{*}$ & $0.56^{*}$ & 0.12 & 0.13 \\
EDTA Mn & & & & & $0.64^{*}$ & 0.32 & $0.43^{*}$ & 0.11 & 0.02 \\
$\mathrm{CaCl}_{2} \mathrm{Mn}$ & & & & & & 0.07 & 0.12 & 0.17 & $-0.44^{*}$ \\
\hline
\end{tabular}

*Significant at $P<0.01 ; n=51$

were collected (Table 1). Soils with and without lime treatment $\left(4 \mathrm{~g} \mathrm{Ca}(\mathrm{OH})_{2} / \mathrm{kg}\right)$ were incubated for 2 months at field capacity moisture level. The soils were then split, and either maintained at field capacity or at saturated moisture level after sowing with ryegrass seeds. Soil $0.05 \mathrm{M} \mathrm{CaCl}_{2}$-extractable $\mathrm{Co}$ and $\mathrm{Mn}$, and 0.02M EDTA-extractable $\mathrm{Co}, \mathrm{Mn}$, $\mathrm{Fe}$ and $\mathrm{Al}$ were determined together with pasture Co.

\section{Analytical methods}

$\mathrm{Mn}, \mathrm{Fe}$ and $\mathrm{Al}$ in soil extracts and digests, and $\mathrm{Mn}$ and Fe in pasture digests were determined directly by Flame Atomic Absorption Spectrophotometry. Co in EDTA extracts and digests was determined directly by Graphite Furnace Atomic Absorption Spectrophotometry (GFAAS). $\mathrm{Co}$ in $\mathrm{CaCl}_{2}$ extracts and pasture digests was determined after extraction of the nitroso-Rcomplex with 4-methyl pentan-2-one (MIBK) by GFAAS (Poole 1980). Separate sets of standards were prepared for each of the chemical reagents. All extractions and analyses were carried out in duplicate.

\section{Results and discussion}

\section{Co and Mn in New Zealand soils}

Highly significant correlations were observed between Total $\mathrm{Co}$ and Total $\mathrm{Mn}, \mathrm{Fe}$ and $\mathrm{Al}$, and EDTA-extractable Co and Mn (Table 2). EDTAextractable Co was correlated with Total, EDTA, $\mathrm{CaCl}_{2}$-extractable $\mathrm{Mn}$ (Figure 1). It is obvious that a high proportion of the Co in soil is bound to $\mathrm{Mn}$ oxides (Childs 1975; Taylor \& McKenzie 1966). $\mathrm{CaCl}_{2}$-extractable $\mathrm{Co}$ and $\mathrm{Mn}$ were correlated with each other, and both were negatively correlated with
Figure 1 The relationship between soil 0.02M EDTA Co and 0.02M EDTA Mn in 51 topsoils.



Soil 0.02M EDTA extractable Mn $(\mu \mathrm{g} / \mathrm{g})$

soil pH (Figure 2). However $\mathrm{CaCl}_{2}$-extractable Co was not significantly correlated with any other soil property (Table 2).

Total Co values ranged from 0.44 to $14.6 \mu \mathrm{g} / \mathrm{g}$ (mean 5.33), EDTA-extractable Co from 0.04 to $5.69 \mu \mathrm{g} / \mathrm{g}$ (mean 1.31) and $\mathrm{CaCl}_{2}$-extractable $\mathrm{Co}$ from 0.004 to $0.406 \mu \mathrm{g} / \mathrm{g}$ (mean 0.083). Soils developed from materials with low ferromagnesian mineral contents, such as pumice soils, usually have a low abundance of Co. Total Mn values ranged from 50 to $3208 \mu \mathrm{g} / \mathrm{g}$ (mean 640), EDTA-extractable Mn from 17 to $1514 \mu \mathrm{g} / \mathrm{g}$ (mean 248) and $\mathrm{CaCl}_{2}$ extractable Mn from 6.25 to $129 \mu \mathrm{g} / \mathrm{g}$ (mean 48.6). 
Table 3

Linear correlation coefficients $(r)$ between pasture $\mathrm{Co}$ and soil properties in Pot Trial 1.

\begin{tabular}{|c|c|c|c|c|c|c|c|c|c|c|c|c|c|}
\hline & $\begin{array}{l}\text { Soil } \\
\mathrm{pH}\end{array}$ & $\begin{array}{c}\mathrm{CaCl}_{2} \\
\mathrm{Co}\end{array}$ & $\begin{array}{c}\mathrm{CaCl}_{2} \\
\mathrm{Mn}\end{array}$ & $\left(\mathrm{CaCl}_{2} \mathrm{Mn}\right)^{-1}$ & $\begin{array}{l}\text { EDTA } \\
\text { Co }\end{array}$ & $\begin{array}{l}\text { EDTA } \\
\mathrm{Mn}\end{array}$ & $(\text { EDTA Mn })^{-1}$ & $\begin{array}{l}\text { EDTA } \\
\mathrm{Fe}\end{array}$ & $\begin{array}{l}\text { Total } \\
\text { Co }\end{array}$ & $\begin{array}{l}\text { Total } \\
\mathrm{Mn}\end{array}$ & $(\text { Total Mn })^{-1}$ & $\begin{array}{l}\text { Total } \\
\mathrm{Fe}\end{array}$ & $\begin{array}{c}\text { Total } \\
\text { Al }\end{array}$ \\
\hline $\begin{array}{l}\text { Pasture Co } \\
\text { (No Co added) }\end{array}$ & 0.14 & -0.21 & -0.62 & $0.85^{*}$ & $-0.64^{*}$ & -0.45 & $0.79^{*}$ & 0.30 & $-0.78^{*}$ & -0.48 & $0.72^{*}$ & -0.57 & -0.50 \\
\hline $\begin{array}{l}\text { Pasture Co } \\
\text { (Co added) }\end{array}$ & 0.17 & -0.19 & -0.62 & $0.74^{*}$ & $-0.67^{\star}$ & -0.48 & $0.71^{*}$ & 0.19 & $-0.83^{*}$ & -0.52 & $0.82^{*}$ & $-0.67^{\star}$ & -0.55 \\
\hline
\end{tabular}

However, there was no clear rela-tionship between soil Mn levels and soil orders.

Air-drying of samples, a common practice in most soil laboratories, caused a substantial increase in $\mathrm{CaCl}_{2}$-extractable Co compared with fresh soil samples. One possible explanation for this phenomenon is that during the air drying processing, microbes in soils may be capable of coupling oxidation of organic $\mathrm{C}$ to reduction of soil Mn oxides, thus increasing the soluble and exchangeable Mn. Because soil Co has a close association with soil Mn oxides, reduction of $\mathrm{Mn}$ oxides will correspondingly increase easily extractable Co.

\section{Pot trials}

Trial 1: There was no significant moisture effect between field capacity and $70 \%$ field capacity on pasture Co. Pasture Co contents, both with and without the Co treatment, had significant negative correlations to total soil $\mathrm{Co}$, 0.02M EDTA-extractable Co, 0.05M $\mathrm{CaCl}_{2}$-extractable $\mathrm{Mn}$, total soil $\mathrm{Mn}$, Fe and Al, and 0.02M EDTA-extractable soil Mn (Table 3, Figure 3). There was a linear relationship between pasture Co and the inverse of each of the measures of soil Mn. The pasture Co results provided more evidence that acid digestion and/or strong extraction, such as EDTA, dissolves Mn fractions, along with Co that is not available to plants. For pumice soils, which have low native $\mathrm{Mn}$ and Co in their parent material, EDTA extraction would not introduce significant errors. In contrast EDTA extraction is a very poor indicator of Co availability in soils that have high Mn levels in their secondary minerals.

There was almost no pasture Co response to Co fertiliser on the soils with high Mn concentration (Figure 3). The magnitude of the pasture Co response
Figure 2 The relationship between soil pH and soil $0.05 \mathrm{M} \mathrm{CaCl}_{2}$ Co in 51 topsoils.

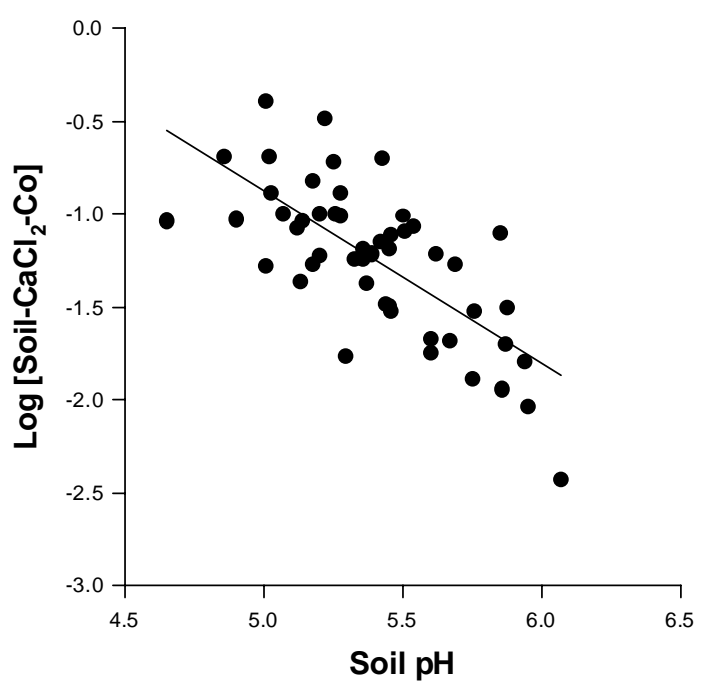

Figure 3 Effect of added Co fertiliser and soil $\mathrm{Mn}$ status, measured by $0.05 \mathrm{M}$ $\mathrm{CaCl}_{2}$ extract, on pasture Co levels in Pot Trial 1.

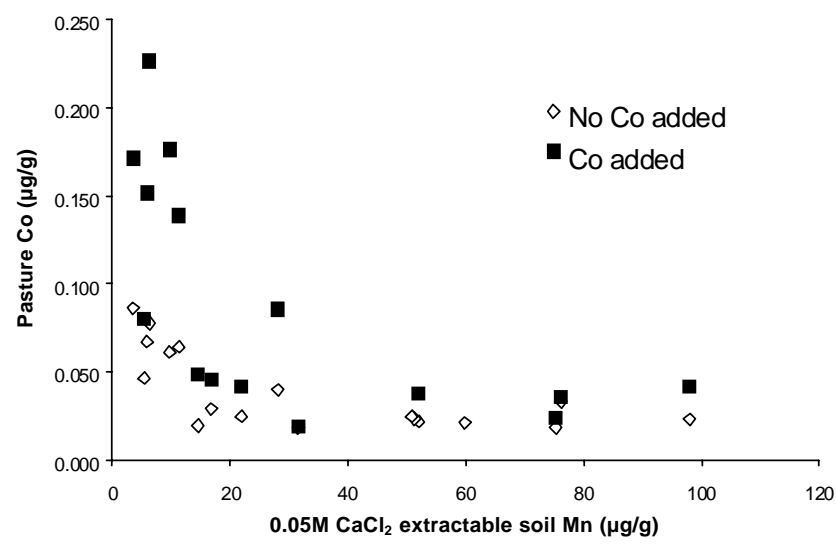

was also linearly related to the inverse of soil $\mathrm{Mn}$ status. It is concluded that soil Mn plays a crucial role in soil Co status and has significant effects on plant Co uptake. 
Figure 4 Effect of lime, soil moisture status and soil groups on pasture Co in Pot Trial 2.

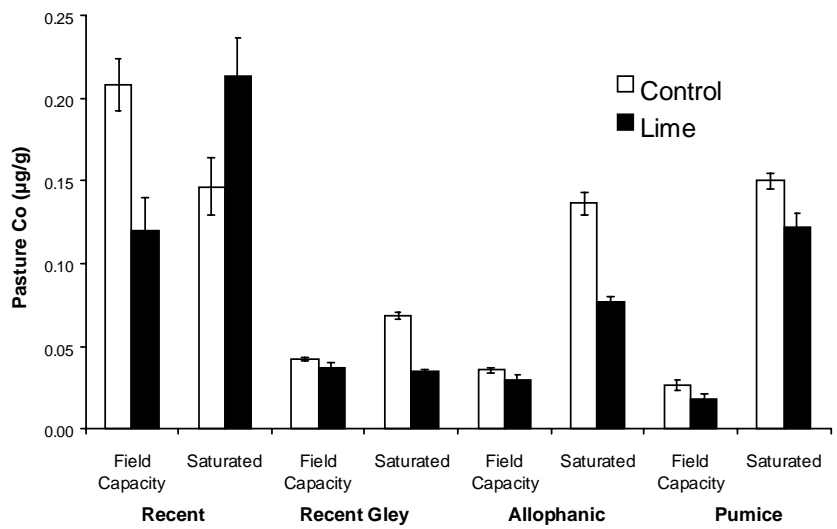

Figure 5 Effect of lime, soil moisture status and soil groups on $0.05 \mathrm{M} \mathrm{CaCl}_{2}$ extractable Co measured after harvest in Pot Trial 2.

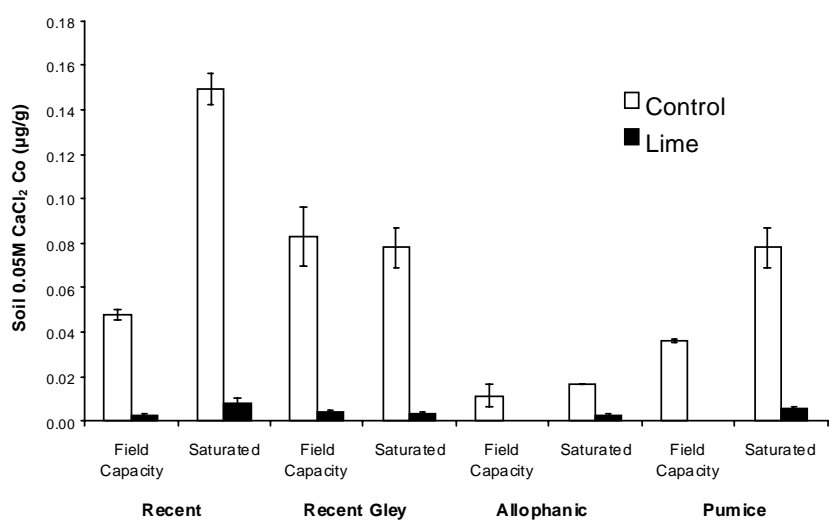

for soils held at field capacity, but the relationship did not hold under saturated conditions.

\section{Conclusions}

In New Zealand soils, there is a close association between total and EDTAextractable Co and soil Mn status. Soil Co is significantly influenced by soil Mn status through the strong fixing ability and the redox reactions of $\mathrm{Mn}$ oxides. As a result of the chemical reactivity of $\mathrm{Mn}$ oxides, and the soil microbial involvement in the Mn redox system, soil Mn status can change dramatically over short distances and times.

The efficacy of Co fertiliser topdressing is also largely controlled by soil Mn. On soils with high Mn, Co fertiliser has limited effectiveness in raising pasture Co concentrations.

If soil $\mathrm{Mn}$ is high, the $0.02 \mathrm{M}$ EDTA extraction, which is currently used by AgResearch as a soil Co assessment in farm surveys, over-estimates the potential Co available for pasture uptake. Because EDTA is strong enough to dissolve the Mn oxides along with the soil organic matter, this obscures the $\mathrm{pH}$ effects on soil Co availability. However $\mathrm{CaCl}_{2}$-extractable $\mathrm{Co}$ is too sensitive to soil $\mathrm{pH}$ to be a suitable extractant.

In the glasshouse $\mathrm{CaCl}_{2}$-extractable $\mathrm{Mn}$ was the best predictor of Co availability. Saturated soil conditions generally increased pasture Co and lime reduced pasture Co.

Trial 2: Apart from the saturated recent soil, all soils showed the same pattern to lime treatment for pasture Co (Figure 4) and $0.05 \mathrm{M} \mathrm{CaCl}_{2}$-extractable Co (Figure 5). The lime treatment reduced $0.05 \mathrm{M}$ $\mathrm{CaCl}_{2}$-extractable Co to less than $0.01 \mu \mathrm{g} / \mathrm{g}$. The reduction of pasture Co caused by increased $\mathrm{pH}$ was relatively less than for $0.05 \mathrm{M} \mathrm{CaCl}_{2}$-extractable Co. $\mathrm{CaCl}_{2}$-extractable $\mathrm{Co}$ is thus too sensitive to $\mathrm{pH}$ to be used for prediction of plant Co. The $\mathrm{pH}$ buffer effect around the rhizosphere may be a reasonable explanation. Pasture $\mathrm{Co}$ and $0.05 \mathrm{M} \mathrm{CaCl}_{2}$ extractable Co from soils under saturated moisture conditions were generally higher than from soils at field capacity. Mn oxides would be reduced under saturated moisture conditions and thus release $\mathrm{Co}^{2+}$ associated with them. A linear relationship between pasture Co and the inverse of soil EDTA extractable $\mathrm{Mn}$, with a different slope for limed soils, was found

\section{ACKNOWLEDGEMENTS}

The authors would like to acknowledge the funding of this work by Meat New Zealand.

\section{REFERENCES}

Adams, S.N.; Honeysett, J.L.; Tiller, K.G.; Norrish, K. 1969. Factors controlling the increase of cobalt in plants following the addition of a cobalt fertilizer. Australia journal of soil research 7: 29-42.

Andrews, E.D. 1970. Cobalt and animal health in New Zealand. New Zealand agricultural science 5: 1115.

Childs, C.W. 1975. Composition in iron-manganese concretions from some New Zealand soils. Geoderma 13: 141-152. 
Forbes, E.A. 1976. Cobalt, copper and zinc in yellowbrown pumice soils under grazed permanent pasture. New Zealand journal of agricultural research 19: 153-164.

Kidson, E.B. 1937. Cobalt status of New Zealand soils. New Zealand journal of science and technology 18: 694-707.

McLaren, R.G.; McLenaghen, R.D.; Swift, R.S. 1987. Micronutrient studies in Southland. A report to the Southland Co-operative Phosphate company and the New Zealand Fertilizer Manufacturer's Research Association. Department of Soil Science, Lincoln College.

Metherell, A.K. 1989. The cobalt enigma - some observations and strategies for Otago and Southland. Proceedings of New Zealand Grassland Association 50: 101-108.

O’Conner, M.B.; Morton, J.D.; Waller, J.E.; Hawke, M.F.; Addison, B. 1995. Soil and plant cobalt status in farm surveys in the Central North Island and Southland. pp. 286-291. In: Fertilizer Requirements of Grazed Pasture and Field Crops: Macro- and
Micro- nutrients. Occasional Report No. 8. Eds. Currie, L.D.; Longanathan, P. Palmerston North, Fertilizer and Lime Research Centre, Massey University.

Poole, P.R. 1980. Graphite furnace atomic absorption spectroscopic determination of cobalt and copper in herbage. Proceedings of New Zealand Institute of Chemistry Conference, August 1980, Palmerston North, New Zealand.

Sherrell, C.G. 1990. Effect of cobalt application on the cobalt status of pastures 2 . Pastures without previous cobalt application. New Zealand journal of agricultural research 33: 305-311.

Sherrell, C.G.; Percival, N.S.; Gee, T.M. 1990. Effect of cobalt application on the cobalt status of pastures 1. Pastures with history of regular cobalt application. New Zealand journal of agricultural research 33: 295-304.

Taylor, R.M.; McKenzie, R.M. 1966. The association of trace elements with manganese minerals in Australian soils. Australian journal of soil research 4: 29-39. 
